\title{
Identifikasi Efektifitas Pembelajaran Trigonometri Kelas X Masa Pandemi Covid 19 Melalui Whatsapp Group
}

\author{
Armiati ${ }^{*}$, Agung Setia Budi ${ }^{2}$ \\ ${ }^{1,2}$ Universitas Negeri Padang, Padang, Sumatera Barat 25111, Indonesia \\ Pengiriman: 25/September/2020; Diterima: 25/Maret/2021; Publikasi: 31/Maret/2021 \\ DOI: https://doi.org/10.31629/jg.v6i1.2539
}

\begin{abstract}
Abstrak
Pada masa pandemi covid-19, sekolah diwajibkan untuk mematuhi aturan belajar dalam jaringan (daring). Tujuannya adalah untuk memutus mata rantai covid-19 dengan menjaga jarak (physical distancing). Situasi pandemi membuat guru dan pemerintah terus berupaya memberikan yang terbaik dalam menyampaikan materi pelajaraan kepada siswa secara daring. Penelitian ini bertujuan untuk mengidentifikasi efektifitas pembelajaran trigonometri di kelas X melalui whatsapp group pada masa pandemi. Penelitian dilakukan pada siswa kelas X IPA 1 di SMAN 3 Rejang Lebong. Teknik pengumpulan data dilakukan melalui wawancara dan anlisis dokumen. Teknik analisis data mengunakan statistic deskriptif. Hasil dari penelitian menunjukkan bahwa terdapat beberapa kendala dalam proses pembelajaran matematika menggunakan whatsapp group yaitu keterbatasan jaringan internet bagi siswa yang bertempat tinggal jauh dari perkotaan dan beberapa siswa yang merasa terbebani dalam memenuhi kebutuhan kuota internet. Selain itu, diperlukan bimbingan dan respons langsung (realtime response) dari guru agar dapat membantu siswa memahami materi pada saat pembelajaran melalui Whatsapp group.
\end{abstract}

Kata Kunci: pandemi covid-19; pembelajaran matematika; pembelajaran daring melalui whatapp group.

\begin{abstract}
During the Covid-19 pandemic, schools were required to comply with online learning rules. The goal is to break the covid-19 chain by maintaining a distance (physical distancing). The pandemic situation has made teachers and the government continue to strive to provide their best in delivering learning materials to students online. This study aims to identify the effectiveness of trigonometric learning in class X through WhatsApp group during the pandemic. The research was conducted on students of class X IPA 1 at SMAN 3 Rejang Lebong. Data collection techniques were carried out through interviews and document analysis. The data analysis technique used descriptive statistics. The results of the study indicate that there are several obstacles in the process of learning mathematics using WhatsApp group, namely the limitations of the internet network for students who live far from cities and some students who feel burdened in fulfilling the internet quota needs. In addition, direct guidance and response (realtime response) from the teacher is needed so that it can help students understand the material during learning through the Whatsapp group.
\end{abstract}

Keywords: covid-19 pandemic; mathematics learning; online learning through whatsapp group

*Penulis Korespondensi

Email Address : Armiati@fmipa.unp.ac.id

Handphone $\quad:+6281363012217$ 


\section{JURNAL GANTANG. Maret 2021; VI(1): 11 - 17 \\ p-ISSN. 2503-0671 \\ e-ISSN. 2548-5547}

\section{Pendahuluan}

COVID-19 pada saat ini sangatlah berpengaruh, hal tersebut telah memaksa semua kebijakan social distancing, atau dikenal pula physical distancing (untuk menjaga jarak fisik), dilakukan sebagai upaya unuk meminimalisir dan mencegah sebaran virus COVID-19. Secara umum, kebijakan itu dibuat sebagai upaya memperlambat laju sebaran COVID-19 di lingkungan masyarakat. Pemerintah telah mengupayakan pencegahan COVID-19 di lingkungan Pendidikan yakni dengan kebijakan "belajar dari rumah" melalui pembelajaran daring dan disusul dengan kebijakan peniadaan Ujian Nasional untuk tahun ini (Kemendikbud 2020).

Teknologi kini sudah masuk kedunia semua kalangan masyarakat tidak terkecuali pada anak-anak. Disebutkan bahwa abad 21 ini mengarah ke digital student dimana siswa lebih banyak meghabiskan waktu di depan layar computer, laptop, atau smartphone untuk bermain games, menyaksikan video, berselancar di social media dan mendengarkan musik secara online (Heru 2018). Kondisi ini membuat seakan jaringan internet menjadi kebutuhan utama bagi sebagian masyarakat. Lebih dari setengah penduduk Indonesia telah bisa mengakses internet. Bahkan sebagian besar pengguna internet menggunakan handphone atau smartphone. Fenomena ini dapat digunakan sebagai salah satu solusi dari adanya pandemi, yaitu dengan belajar dari rumah seperti yang dianjurkan pemerintah untuk memutus penyebaran COVID-19.

Partayasa (2020) mengatakan bahwa sudah terjadi perubahan pembelajaran dari konvensional menjadi pembelajaran dengan keterbukaan akses informasi dan pemanfaatan teknologi. Grand-Clement et al ( 2017) menyebutkan bahwa dunia digital telah semakin mempengaruhi dunia pendidikan dan keterampilan melalui inovasi-inovasi di dalam melakukan proses pendidikan. Adanya pengaruh digital ini dapat dimanfaatkan untuk mengatasi masalah pembelajran di masa pandemi. Untuk memenuhi hal tersebut diperlukan media belajar yang membuat siswa tertarik untuk belajar dan dapat mengatasi kejenuhan dan kebosanan siswa dalam belajar (Fadillah and Bilda 2019).

Pengintegrasaian Science, Technology, Engineering dan Mathematics (STEM) dalam pembelajaran bertujuan untuk menyiapkan peserta didik dalam menyongsong persaingan dunia global (Widya, Rifandi, and Laila Rahmi 2019). Adanya penitegrasian teknologi dalam pembelajaran menuntut guru memahami bagaimana menjalankan tugasnya dalam situasi yang baru yaitu belajar dari rumah, dengan memanfaatkan teknologi berupa computer, laptop, ataupun smartphone. Proses pembelajaran jarak jauh yang memanfaatkan teknologi ini dikenal sebagai e-learning.

Disebutkan bahwa e-learning sebagai media pembelajaran mampu menambah antusias siswa dan memberikan pengalaman baru bagi siswa (Heru, 2018). Anjuran belajar dari rumah akibat pandemi ini membuat interaksi antara guru dan siswa berubah menjadi secara langsung dan/atau tidak langsung. Pembelajaran dapat dilakukan secara langsung seperti Chatting lewat koneksi internet atau secara tidak langsung seperti mengirim tugas via email. Agustina (2016) menyebutkan bahwa proses pembelajaran menggunakan e-learning menjadi lebih unggul daripada proses pembelajaran tradisional.

Hal tersebut sejalan dengan pendapat Herliandry (2020) bahwa pembelajaran online memberikan kemudahan dalam memberikan transfer informasi pada berbagai situasi dan kondisi. Pembelajaran online yang menyediakan berbagai platform mulai dari diskusi hingga tatap muka secara virtual memberikan banyak manfaat bagi penggunanya. Firman \& Rahayu, (2020) menyebutkan bahwa pembelajaran online memudahkan dalam melakukan transfer informasi pada berbagai situasi dan kondisi.

Media sosial WhatsApp (WA) merupakan salah satu media komunikasi yang saat ini banyak digunakan oleh seluruh lapisan masyarakat. Aplikasi yang disediakan dapat memudahkan pengguna untuk berkomunikasi 
jarak jauh bahkan bisa langsung melihat satu sama lain seperti video call. Yensy (2020) menyebutkan Whatsapp merupakan salah satu media pembelajaran jarak jauh yang sudah familiar dan sering digunakan. Iskandar, (2020) dalam penelitiannya menyimpulkan bahwa penggunaan aplikasi whatsapp dapat membantu siswa dalam proses pembelajaran dan juga dapat membantu siswa yang tidak dapat hadir saat pembelajaran berlangsung sehingga tidak ketinggalan pelajaran

Whatsapp merupakan salah satu aplikasi chatting yang bisa digunakan untuk mengirim pesan teks, gambar, suara, lokasi dan juga video ke orang lain dengan menggunakan smartphone jenis apapun (Jubile Enterprise dalam Yensy, 2020). Aplikasi ini dalam penggunaannya sebagai media chat digital menjadi satu kesatuan yang lengkap membantu masyarakat dalam menjalin komunikasi di seluruh belahan dunia.

Armiati (2019) menjelaskan dengan menggunakan pembelajaran berbasis video, pembelajaran kelas bisa lebih efektif, guru tidak perlu mengulang presentasi materi pembelajaran di banyak kelas lain, tetapi mereka dapat menggunakan media yang disiapkan. Hal ini mungkin bisa diterapkan pada masa belajar dari rumah, karena pelajaran dari sekolah dapat diberikan melalui teknologi via WA Group yang ada di handphone. Artinya guru dapat mengirimkan vidio pembelajarannya melaui WA. Untuk selanjutnya siswa dan guru bisa berdiskusi melalui chatting di grup yang sama. Keadaan ini masih menjadi perbincangan dalam proses pembelajaran matematika. Berdasarkan penelitian Yensy (2020) pembelajaran jarak jauh masih belum memberikan hasil yang lebih baik dibandingkan pembelajaran langsung secara konvensional. Pemebelajaran jarak jauh ini dibantu dengan media berupa handphone android. Mitha Frilia dkk (2020) menjelaskan bahwa media pembelajaran berbasis android juga dapat digunakan dengan efektif untuk pembelajaran matematika.

Berdasarkan informasi terkait pembelajaran matematika pada salah satu SMA di Bengkulu yakni SMAN 3 Rejang Lebong pada bulan Juli tahun 2020, diketahui bahwa pembelajaran dari rumah telah dilakukan selama masa pandemic COVID-19. Proses pembelajan dilakukan secara daring (dalam jaringan) yaitu menggunakan video, pengiriman modul pembelajaran, dan diskusi melalui WA Group. Selama proses pembelajaran guru memberikan informasikan ke siswa melalui WA Group. Di setiap media diberikan beberpa soal latihan yang digunakan untuk mengevaluasi pelaksanaan pembelajaran

Materi trigonometri adalah salah satu materi yang diajarkan di saat pandemi. Materi ini merupakan salah satu materi yang harus diajarkan di kelas $\mathrm{X}$. Trigonometri merupakan materi yang abstrak yang selama ini tergolong materi yang sulit untuk dipahami siswa. Masih banyak siswa yang bermasalah dalam menentukan nama sisi pada segitiga siku-siku, yang berakibat mereka terkendala dalam konsepkonsep lainnya. Hal ini juga di ungkapkan Fajri and Nida (2019) bahwa siswa tidak paham dalam mendefinisikan konsep trigonometri (sinus, cosinus, tangen). Kesulitan dalam memahami prinsip disebabkan karena siswa kesulitan dalam melakukan operasi hitung serta tidak bisa menentukan nilai perbandingan trigonometri pada sudut istimewa. Jatisunda (2019) dan Wulandari and Gustell (2020) dalam penelitiannya menemukan kesulitan mempelajari ide-ide tentang trigonometri, terutama konsep segitiga siku-siku. kesalahan konsep pythagoras, dan kesalahan penggunaan rumus serta kesalahan menentukan perbandingan nilai trigonometri.

Beberapa penelitian lainnya yaitu Siti Sofiyah (2018:23), Hülya Gür (2009:68), dan Blackett \& Tall, 1991 dalam Keith Weber (2005:91) juga menyebutkan bahwa materi trigonometri merupakan subjek matematika yang diyakini sulit oleh sebagian besar siswa. Disebutkan juga materinya yang abstrak membuat siswa bingung dalam memahami konsep-konsep trigonometri.

Berdasarkan permasalahan diatas melalui tulisan ini akan diidentifikasi efektifitas pembelajaran trigonometri kelas X IPA1 selama masa pandemi COVID-19 melalui whatsapp group, di SMAN 3 Rejang Lebong. 


\section{JURNAL GANTANG. Maret 2021; VI(1): 11 - 17 \\ p-ISSN. 2503-0671 \\ e-ISSN. 2548-5547}

\section{Metode Penelitian}

Jenis penelitian ini adalah penelitian deskriptif. Penelitian ini dilakukan kelas 10 IPA 1 di SMAN 3 Rejang Lebong pada bulan Juli tahun 2020. Berdasarkan uraian pada latar belakang, melalui kajian ini akan diuraikan efektifitas pembelajaran Trigonometri menggunakan whatsapp group. Efektifitas pembelajaran ditinjau dari ketepatan siswa dalam merespon tugas-tugas yang diberikan guru. yaitu dari segi ketepatan waktu pengiriman tugas sesuai batas waktu yang diberikan dan juga ketepatan dalam menjawab tugas yang diberikan.

Pengumpulan data dilakukan melalui rekapitulasi dokumen siswa yaitu pengerjaan tugas siswa selama 8 pertemuan dan wawancara kepada 9 orang siswa. Teknik analisis data yang digunakan yaitu statistic deskriptif. Dokumen siswa yang dianalisis di bagi menjadi tiga kriteria yaitu mengumpulkan tugas tepat waktu, mengumpulkan tugas terlambat, dan tidak mengumpulkan tugas sama sekali. Data dikelompokkan berdasarkan hasil persentase dari jumlah siswa. Kemudian dilakukan wawancara langsung kepada 3 orang siswa pada masing kategori yaitu kategori tepat waktu, terlambat, dan tidak mengumpulkan tugas sama sekali. Siswa yang dipilih berdasarkan siswa yang minimal 6 kali pertemuan masuk kedalam kategori tepat waktu, terlambat, dan tidak sama sekali mengumpulkan tugas. Wawancara dilakukan terkait system pembelajaran yang diberikan dan kendala yang dihadapi siswa selama pembelajaran berlanggsung.

\section{Hasil dan Pembahasan}

Beradasarkan uraian pada latar belakang, melalui kajian ini akan diuraikan efektifitas pembelajaran Trigonometri menggunakan whatsapp group. Temuan dalam penelitian ini menunjukkan masih ada siswa yang tidak mengumpulkan tugas dan tidak semua siswa ikut aktif dalam pembelajaran. Dari analisis di peroleh data pengiriman tugas yang diberikan oleh 30 orang siswa beserta keterangan waktu pengumpulan tugasnya. Data hasil analisis disajikan dalam tabel 1. Berdasarkan data pada tabel 1 terlihat bahwa rata-rata ada $32 \%$ siswa dapat mengumpulkan tugas tepat waktu, sebanyak 40,9\% siswa mengumpulkan tugas terlambat, dan sebanyak $27,1 \%$ siswa tidak mengumpulkan tugas sama sekali selama 8 pertemuan pelajaran. Berdasarkan data tersebut diketahui bahwa persentase siswa dalam mengumpulkan tugas disetiap pertemuan selalu berubah.

Tabel 1.

Data pengumpulan tugas siswa

\begin{tabular}{llll}
\hline \multirow{2}{*}{$\begin{array}{l}\text { Pertemuan } \\
\text { Ke }-\end{array}$} & $\begin{array}{l}\text { Tepat } \\
\text { waktu }\end{array}$ & Terlambat & $\begin{array}{l}\text { Tidak } \\
\text { sama } \\
\text { sekali }\end{array}$ \\
\cline { 2 - 4 } 1 & $\begin{array}{l}8 \text { orang } \\
(27 \%)\end{array}$ & $\begin{array}{l}12 \text { orang } \\
(40 \%)\end{array}$ & $\begin{array}{l}10 \text { orang } \\
(33 \%)\end{array}$ \\
\hline 2 & $\begin{array}{l}7 \text { orang } \\
(23 \%)\end{array}$ & $\begin{array}{l}15 \text { orang } \\
(50 \%)\end{array}$ & $\begin{array}{l}8 \text { orang } \\
(27 \%)\end{array}$ \\
\hline 3 & $\begin{array}{l}7 \text { orang } \\
(23 \%)\end{array}$ & $\begin{array}{l}11 \text { orang } \\
(37 \%)\end{array}$ & $\begin{array}{l}12 \text { orang } \\
(40 \%)\end{array}$ \\
\hline 4 & $\begin{array}{l}13 \text { orang } \\
(43 \%)\end{array}$ & $\begin{array}{l}8 \text { orang } \\
(27 \%)\end{array}$ & $\begin{array}{l}9 \text { orang } \\
(30 \%)\end{array}$ \\
\hline 5 & $\begin{array}{l}10 \text { orang } \\
(33 \%)\end{array}$ & $\begin{array}{l}12 \text { orang } \\
(40 \%)\end{array}$ & $\begin{array}{l}8 \text { orang } \\
(27 \%)\end{array}$ \\
\hline 6 & $\begin{array}{l}8 \text { orang } \\
(27 \%)\end{array}$ & $\begin{array}{l}9 \text { orang } \\
(30 \%)\end{array}$ & $\begin{array}{l}13 \text { orang } \\
(43 \%)\end{array}$ \\
\hline 7 & $\begin{array}{l}13 \text { orang } \\
(43 \%)\end{array}$ & $\begin{array}{l}15 \text { orang } \\
(50 \%)\end{array}$ & $\begin{array}{l}2 \text { orang } \\
(7 \%)\end{array}$ \\
\hline 8 & $\begin{array}{l}11 \text { orang } \\
(37 \%)\end{array}$ & $\begin{array}{l}16 \text { orang } \\
(53 \%)\end{array}$ & $\begin{array}{l}3 \text { orang } \\
(10 \%)\end{array}$ \\
\hline $\begin{array}{l}\text { Rata-rata } \\
\text { persentase }\end{array}$ & $32 \%$ & $\begin{array}{l}40,9 \% \\
27,1 \%\end{array}$ \\
\hline
\end{tabular}

Berdasarkan hasil wawancara dengan beberapa siswa, secara umum hal ini disebabkan oleh kondisi yang baru di hadapi oleh siswa. Sebagian besar siswa merasa kurang siap menghadapi program belajar dari rumah ini. Ketidaksiapan itu terutama terkait ketersediaan jaringan dilingkungan tempat siswa tinggal. Jaringan yang sering bermasalah di lokasi tempat tinggal siswa membuat siswa sulit mencerna informasi yang diberikan guru melalui WA. Hal ini menyebabkan proses transfer informasi lewat media online tidak bisa berjalan dengan baik ( Herliandry 2020). Masalah lainnya adalah beberapa siswa belum memiliki handphone sehingga harus meminjam kepada teman atau 
saudara. Terkait hal ini guru memberikan kelonggaran dalam pengumpulan tugas kepada siswa yang terlambat dengan batas waktu yaitu paling lambat pengumpulan sebelum pertemuan berikutnya.

Hasil wawancara kepada 3 orang siswa yang termasuk kedalam kategori mengumpulkan tugas tepat waktu juga mengalami kendala dalam proses pembelajaran trigonometri. Umumnya mereka sulit untuk memahami materi yang telah diberikan guru. Meskipun diberi kesempatan untuk bertanya, tetapi penjelasan yang diberikan guru melalui WA masih belum dapat dicerna dengan baik oleh siswa. Terkadang ada siswa yang mengalami kesulitan dalam memahami materi trigonometri yang diberikan guru dan ingin bertanya, tetapi tidak tahu bagaimana cara bertanya kepada guru. Akibatnya mereka hanya mengumpulkan tugas seadanya untuk memenuhi bahwa mereka mengerjakan tugas dan mengumpulkan tugas tepat waktu. Hal ini diketahui dari pernyataan guru bahwa siswa yang tepat waktu masih banyak yang belum benar dalam mengerjakan tugas-tugas materi trigonometri.

Hasil wawancara kepada 3 orang siswa yang terlambat mengumpulkan tugas adalah cukup sulit untuk mengikuti program belajar dari rumah ini karena terkendala dengan fasilitas seperti handphone karena beberapa siswa masih belum mempunyai handphone sehingga harus berupaya membeli atau meminjam kepada orang lain. Lokasi rumah siswa yang masih minim sinyal juga merupakan masalah, bagi siswa yang masih tinggal jauh dari perkotaan. Untuk bisa mengikuti pembelajaran dan mengumpulkan tugas secara daring mereka harus menunggu atau mencari lokasi yang memiliki sinyal baik. Hal inilah yang menjadikan beberapa siswa terlambat dalam mengumpulkan tugas.

Hasil wawancara dengan 3 orang siswa yang sama sekali tidak mengumpulkan tugas adalah hampir sama dengan siswa yang sering terlambat mengumpulkan tugas, yaitu tidak memiliki Handphone dan terkendala jaringan. Informasai dari guru dalam pembelajaran di sekolah sebelum adanya pandemi siswa-siswa ini juga memiliki motivasi yang rendah dalam belajar. Artinya untuk siswa yang tidak mengumpulkan tugas sama sekali bukan hanya permasalahan fasilitas belajar, tetapi juga kurangnya kesadaran siswa terhadap pentingnya pelajaran.

Permasalahan lainnya yang dihadapi siswa untuk semua kelompok adalah mereka juga harus membeli kuota untuk mengakses internet, apabila siswa tidak memiliki kuota yang cukup maka akan sulit untuk mengikuti pelajaran dengan baik. Beberapa siswa juga baru menggunakan Whatsapp sehingga cukup sulit untuk mengikuti teman-teman yang lain karena harus membiasakan diri terlebih dahulu.

Hasil tugas yang dikumpulkan siswa terkait materi trigonometri masih belum maksimal. Hal ini di ungkapkan oleh guru matematika yang mengajar bahwa tugas yang dikerjakan masih banyak salah. Hanya 1/3 dari jumlah rata-rata siswa yang mengumpulkan tugas yang dapat menjawab dengan benar. Kesalahan yang paling banyak terjadi adalah kesalahan operasi hitung aljabar, pemahaman konsep rumus trigonometri dan pengaplikasian rumus ke soal yang masih salah. Hal ini sesuai dengan temuan Fajri and Nida (2019) yaitu siswa sulit untuk memahami dan mendefinisikan konsep trigonometri.

Selain itu masih ada beberapa jawaban siswa sama persis, baik dari segi langkah pengerjaan dan bentuk penyelesaian, bahkan jika ada jawaban yang salah, kesalahannya juga sama. Ini mengindikasikan tugas yang dibuat hanya menyalin pekerjaan dari satu orang. Karena guru tidak mengamati langsung siswa bekerja, maka tidak diketahui dengan pasti siswa mana yang benar-benar bekerja sendiri dan siswa mana yang hanya menyalin pekerjaan temannya.

Hasil ini mengindikasikan bahwa tujuan pembelajaran trigonometri belum tercapai, karena sebagian besar siswa belum mampu menyelesaikan tugas-tugas yang diberikan guru. Tugas yang dikerjakan masih belum menunjukkan seluruh siswa mencapai tujuan yang telah ditetapkan. Selain kendala yang dihadapi siswa dalam belajar secara daring, tingkat abstraksi materi trigonometri juga dapat menjadi penyebab kesulitan siswa. Hasil ini 


\section{JURNAL GANTANG. Maret 2021; VI(1): 11 - 17 \\ p-ISSN. 2503-0671 \\ e-ISSN. 2548-5547}

sejalan dengan temuan dalam penelitian yang dilakukan Yulandari (2012) dalam Siti Sofiyah (2018:23), Hülya Gür (2009:68), dan Blackett \& Tall, (1991) dalam Keith Weber (2005:91), yang menyebutkan bahwa materi trigonometri sudah dirasakan sulit oleh siswa sejak awal pembelajaran. Jika di awal pembelajaran siswa sudah menemukan masalah, hal ini dapat berdampak pada motivasai belajar siswa, yang akan berdampak pula pada hasil belajarnya.

Biasanya pembelajaran akan mudah dicerna siswa jika ia dapat membayangkan materi itu. Untuk memahami materi trigonometri siswa harus dapat membayangkan situasi nyata dari permasalahan yang diajukan. Melalui WA, tentunya siswa hanya mengamati materi melalui tulisan, seringkali informasi tulisan sulit dipahami oleh siswa. Materi trigonometri juga memuat banyak simbol, hal ini juga dapat menjadi kendala bagi siswa dalam memahami materi yang diberikan melalui WA.

\section{Kesimpulan}

Berdasarkan temuan dalam penelitian ini dapat disimpulkan bahwa pembelajaran matematika materi trigonometri di kelas X IPA 1 SMAN 3 Rejang Lebong melalui Whatsapp Group belum efektif. Persentase rata-rata siswa yang bermasalah dalam mengumpulkan tugas masih cukup besar yaitu sebanyak 40,9\% siswa mengumpulkan tugas terlambat, dan sebanyak $27,1 \%$ siswa tidak mengumpulkan tugas sama sekali. Masalah utama siswa adalah jaringan internet yang tidak stabil, serta tidak memiliki fasilitas untuk belajar secara daring. Selain terkendala dalam fasilitas belajar, siswa juga mengeluhkan kesulitannya dalam mencerna materi dari bahan yang diberikan guru.

Pembelajaran menggunakan Whatsapp Group ini juga belum efektif ditinjau dari pemahaman siswa terhadap konsep trigonometri. Sebagian besar siswa hanya mengerjakan tugas seadanya untuk memenuhi tuntutan ketepatan waktu dalam mengumpulkan tugas. Dari jumlah siswa yang mengumpulkan tugas (tepat waktu atau terlambat) hanya 1/3 (sekitar 7 siswa) yang menjawab benar. Sebagian besar lainnya hanya menyalin pekerjaan temannya, dan jawaban yang disalin itu tidak benar. Melalui media ini guru juga mengalami kesulitan untuk mengtahui secara pasti pemahaman siswa terhadap konsep yang diberikan, karena guru tidak mengamati langsung proses pengerjaan yang dilakukan siswa.

Berdasarkan temuan ini, disarankan dalam pembelajaran matematika umumnya dan khusus materi trigonometri sebaiknya penggunaan WA dibarengi dengan fasilitas lainnya. Misalnya menggunakan vidio pembelajaran yang berisi rekaman penjelasan guru tentang materi yang harus dikuasai siswa. Penggunaan vidio bisa dilakukan siswa secara berulang, jika mereka belum paham.

\section{Referensi}

Agustina, Riska, Paulus Insap Santosa, and Ridi Ferdiana. 2016. Sejarah, tantangan, dan faktor keberhasilan dalam pengembangan e-learning. Seminar Nasional Sistem Informasi Indonesia (November).

Armiati, Yerizon, and Resi Niscaya. 2019. Flipped classroom based mathematics learning equipment for students in grade $\mathrm{X}$ SMA. Journal of Physics: Conference Series 1317(1). doi: 10.1088/17426596/1317/1/012129.

Fadillah, Ahmad, and Westi Bilda. 2019. pengembangan video pembelajaran matematika berbatuan aplikasi sparkoll videoscribe. (2):177-82.

Fajri, Nisya, and Ira Nida. 2019. analisis kesulitan siswa kelas X SMA Negeri 6 Aceh Barat Daya pada materi trigonometri. Jurnal Ilmiah Pendidikan Matematika Al Qalasadi 3(2):12-22. doi: 10.32505/qalasadi.v3i2.1179.

Firman, Firman, and Sari Rahayu. 2020. pembelajaran online di tengah pandemi Covid-19. Indonesian Journal of Educational Science (IJES) 2(2):81-89. doi: 10.31605/ijes.v2i2.659.

Grand-Clement, Sarah, Axelle Devaux, Julie Belanger, and Catriona Manville. 2017. Digital learning: education and skills in the digital age. Digital Learning: Education and Skills in the Digital Age. doi: 10.7249/cf369. 
Gur, Hulya. 2009. Trigonometry Learning. New Horizons in Education, 57(1):67-80.

Herliandry, Luh Devi, Nurhasanah, Maria Enjelina Suban, and Heru Kuswanto. 2020. Pembelajaran pada masa pandemi covid-19 luh. Jurnal Teknologi Pendidikan 22(1):65-70.

Heru. 2018. Jurnal Math Educator Nusantara ( JMEN). Jurnal Math Educator Nusantara 4:157-67. doi: 10.29407/jmen.v4i2.12108.

Iskandar, Resa. 2020. Penggunaan grup whatsapp sebagai media pembelajaran terhadap peserta didik dta at-tawakal kota bandung. Comm-Edu (Community Education Journal) 3(2):97. doi: 10.22460/comm-edu.v3i2.3778.

Jatisunda, Mohamad Gilar. 2019. Kesulitan siswa dalam memahami konsep trigonometri di lihat dari learning obstacles. Didactical Mathematics 2(1):9. doi: 10.31949/dmj.v2i1.1664.

Kemendikbud. 2020. Kemendikbud Bekerja Sama Dengan Operator Telekomunikasi Sukseskan Pembelajaran Di Rumah, 26 Maret 2020, Https:// Www.Kemdikbud.Go.Id/Main / Blog/2020/03/Kemendikbud BekerjaSama-Dengan-Operator TelekomunikasiSukseskan Pembelajaran-Di-Rumah, Diakses 30 M." Retrieved July 17, 2020 (https://www.google.com/search?safe=stri ct\&sxsrf=ALeKk02PBNEntANG2hakhuIOuDsP5DbQA:1594978393447\&q=Ke mendikbud+Bekerja+Sama+dengan+Oper ator+Telekomunikasi+Sukseskan+Pembel ajaran+di+Rumah",+26+Maret+2020,+htt ps://+www.kemdikbud.go.id/main+/+blog/ 2020/03/ke).

Mitha Frilia, Hapizah, Ely Susanti, and Scristia Scristia. 2020. Pengembangan bahan ajar materi prisma berbasis android untuk pembelajaran berbasis masalah di kelas VIII. Jurnal Gantang 5(2):191-201. doi: 10.31629/jg.v5i2.2362.

Partayasa, Wayan. 2020. Pengaruh model pembelajaran creative problem solving (CPS) berbantuan video pembelajaran terhadap kemampuan pemecahan masalah ditinjau dari minat. JNPM (Jurnal Nasional Pendidikan Matematika) 4(1):168. doi: 10.33603/jnpm.v4i1.2644.

Sofiyah, Siti. 2018. Analysis of students error in proving trigonometric identities. International Journal of Management and
Applied Science (5):2394-7926.

Weber, Keith. 2005. Students' understanding of trigonometric functions. Mathematics Education Research Journal 17(3):91-112. doi: 10.1007/BF03217423.

Widya, Ronal Rifandi, and Yosi Laila Rahmi. 2019. STEM education to fulfil the 21st century demand: a literature review. Journal of Physics: Conference Series 1317(1). doi: 10.1088/17426596/1317/1/012208.

Wulandari, Suci, and Merla Ultra Gustell. 2020. Analisis kesalahan menyelesaikan soal trigonometri siswa kelas X SMA. 4(1):6480.

Yensy, Nurul Astuty. 2020. Efektifitas pembelajaran statistika matematika melalui media whatsapp group ditinjau dari hasil belajar mahasiswa (masa pandemik covid 19). 05(02):65-74. 